Ethiopian Journal of Environmental Studies \& Management 8(Suppl. 1): 771 - 781, 2015.

ISSN:1998-0507

doi: http://dx.doi.org/10.4314/ejesm.v8i1.4S

Submitted: May 26, 2015

Accepted: September 21, 2015

\title{
ACCESS TO INFORMATION ABOUT SOLID WASTE MANAGEMENT: IMPLICATIONS ON RESIDENTS' ATTITUDES IN ELDORET MUNICIPALITY, KENYA
}

*JUMA, E.A.B. AND KENDI, E.B.

${ }^{1}$ Moi University, School of Arts and Social Sciences, Department of Geography, P.O. Box 3900 - 3100, Eldoret, Kenya

\begin{abstract}
Access to information about Solid Waste Management (SWM) is critical in changing the negative attitudes of urban residents towards proper handling of waste. This paper focuses on the influence of access to information about SWM on proper solid waste handling by residents in Eldoret Municipality. A survey design was adopted, 170 households were randomly selected, questionnaire and observations used in data collection and analysis done by Statistical Package for Social Sciences Version 16.0. The results indicated that $53.53 \%$ of the respondents were accessible to information about SWM. The friends, neighbours, schools, radio and television were the common source of information. Most respondents sought information less than $1 \mathrm{~km}$ away. The major challenges hindering access to information included lack of interest, few National Environmental Management Authority (NEMA)/Eldoret Municipal Council (EMC) officers, inadequate time, inadequate funds to seek information, and unsupportive legal and regulatory frameworks. Access to information about solid waste mainly promoted separation of solid wastes before disposing, use of dust bins and landfills, reuse and recycling of solid waste, willingness to pay for waste disposal, and enhanced good rapport among stakeholders concerned with SWM. This paper recommends participation of all stakeholders in promoting access to information about solid waste to enhance sustainable SWM.
\end{abstract}

Key Words: Information, Access, Awareness, Solid waste management, Eldoret, Kenya

\section{Introduction}

Urban households contribute greatly to solid waste generation in their environment due to increased population, changes in consumer patterns, and improper planning and building regulations (Minn et al., 2010; Opata et al., 2013). SWM in urban centres has been a source of concern in both developed and developing nations. It has been noted that, although developed nations produce large quantities of solid waste compared to developing ones, they have been successful in mitigating the menace of improper solid waste (Ogwueleka, 2009). This has been attributed to inadequate equipment for waste collection, poor guidelines and supervision, insufficient technical personnel, and low levels of awareness and education about proper SWM in developing countries (NEMA, 2014; Okalebo et al., 2014).

Nevertheless, urban authorities in developing nations like Kenya upon the realization of these challenges, have formulated legal and regulatory framework, provided dustbins for waste collection in urban estates, employed more personnel as well as created awareness (NEMA, 2014). Despite the above 
strategies, in most towns of developing countries residents continue to dump garbage in open pits at the nearest vacant plot, public space, road, river or simply burn it in their backyards (Abul, 2010; Chepkole, 2014; Mukui, 2013). This is evidenced by indiscriminate dumping and littering around the estates. This has a multidimensional impact on human and environmental well being such as pollution of air, soil, water, clogging of drains and creation of stagnant water for insect breeding (Abul, 2010; Chepkole, 2014; Ogwueleka, 2009).

Recently the emphasis has been directed towards participatory approaches in SWM in most developing countries. This involves participation of the concerned actors at various levels to enhance co-operation (Minn et al., 2010). The level of access to information about SWM by urban dwellers is crucial for the success of these participatory initiatives. Awareness and knowledge about sustainable SWM is critical in ensuring waste reduction, reuse, recycling, and resource recovery (Mangizvo, 2010; NEMA, 2014). NEMA (2014) reports that poor attitude towards waste management is due to lack of knowledge and awareness about SWM. According to Sarker et al (2012), most of the residents in Tangail Pourashava in Bangladesh are not adequately informed about the effects of solid waste mismanagement and indiscriminate dumping. In addition, Kapepula et al. (2007) advances that majority of household SWM practices cannot be effective if there is no diffusion of information on safety and environmental awareness to solid waste actors and the entire population.

According to Minn et al (2010), the municipal of Myanmar has been ineffective in diffusing the information, communicating with the residents and convincing them to promote their capacity and change their attitudes. Mukui (2013), reports that although most residents in Nyeri Town were informed about the negative effects of improper solid waste disposal and were formally educated only $26 \%$ engaged in proper management practices. However, due to differences in spatial as well as temporal factors, the findings in Nyeri (Kenya) and Myanmar (Bangladesh) are limited in application in the case of Eldoret Municipality. Although, in Eldoret Municipality recent research have been done on determinants of household SWM (Chepkole, 2014), and household solid waste generation patterns and prevailing management practices (Okalebo et al., 2014) they have not adequately focused on the influence of access to information about SWM and residents' attitude change. This raises a number of questions: Are the urban residents in Eldoret Municipality accessible to information about SWM? If yes to what extent does this influence residents' attitude towards SWM in Eldoret Municipality?

This paper assesses the influence of access to information about SWM on residents' attitudes in Eldoret Municipality. It is guided by the following objectives:

(i) To establish the current level of access to information about SWM by residents.

(ii) To identify the main sources of information about proper SWM by residents.

(iii) To assess the influence of access to information about SWM to residents' attitudes on proper handling of the waste.

(iv) To suggest possible ways of promoting access to information about SWM by residents. 


\section{Methodology}

\section{Study Area}

Eldoret Municipality is located in Uasin Gishu County in Kenya (Figure 1). It lies between $0^{\circ} 31^{\prime} 0^{\prime \prime}$ North (latitudes) $35^{\circ} 17^{\prime} 0^{\prime \prime}$ East (Longitudes). It is found south of the Cherangani Hills and terrain varies from about 2100 metres above sea level at the airport to more than 2700 metres in nearby areas. It is located $312 \mathrm{~km}$ North West of Nairobi (capital city of Kenya). The population of Eldoret is
289,380 according to the 2009 census. It is the fifth largest urban centre in Kenya after Nairobi, Mombasa, Kisumu, and Nakuru in that order. With Eldoret Municipality, Langas is one of the largest informal settlements located seven kilometers from the Central Business District along the Eldoret-Kisumu road (Figure 2). In 1999, Langas Estate had an estimated population of 26,000 (Musyoka, 2004) and according to Simiyu (2012), there are about 1051 households in Langas Estate.

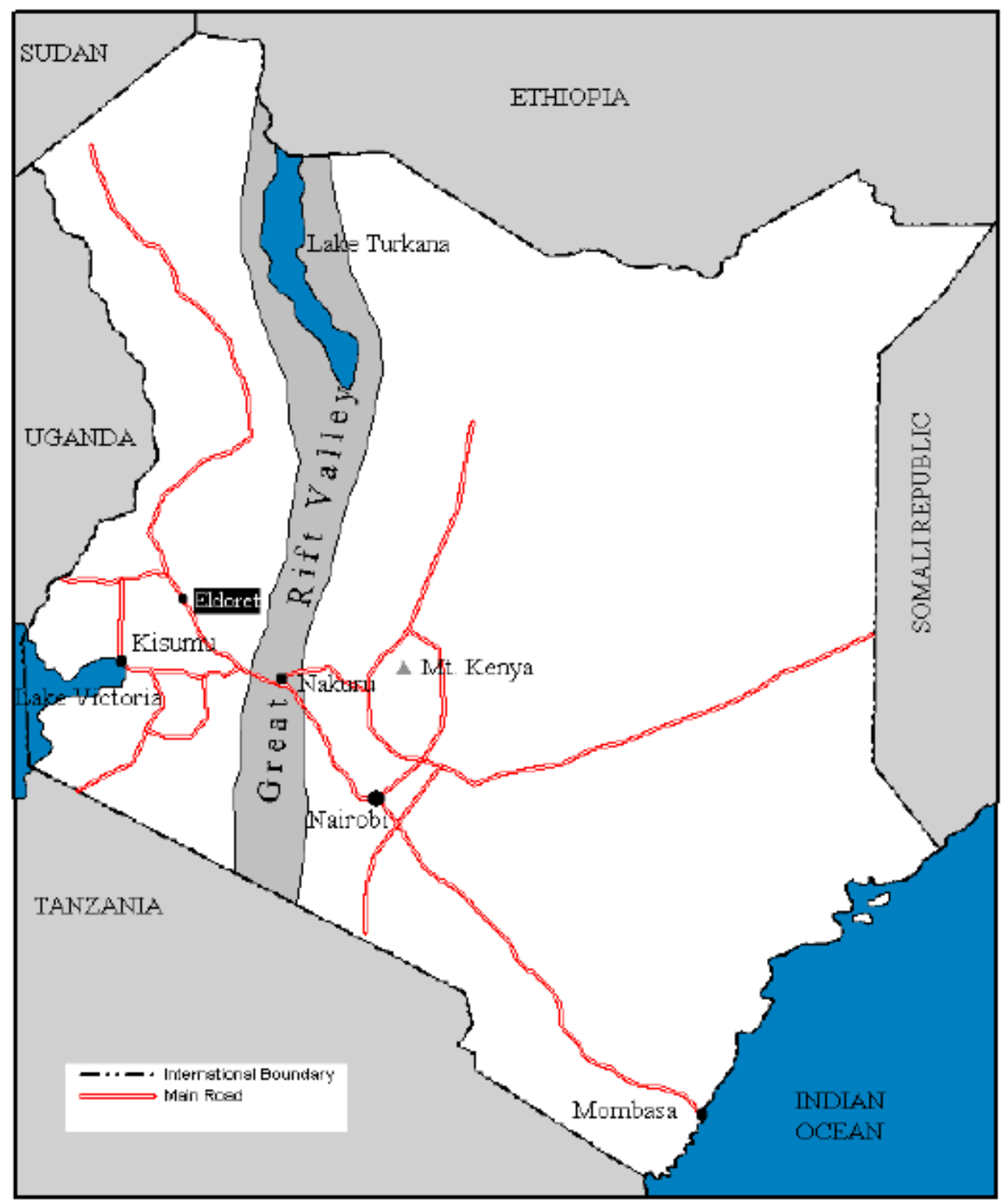

Figure 1: Location of study area in Kenya

Source: (Simiyu, 2012) 


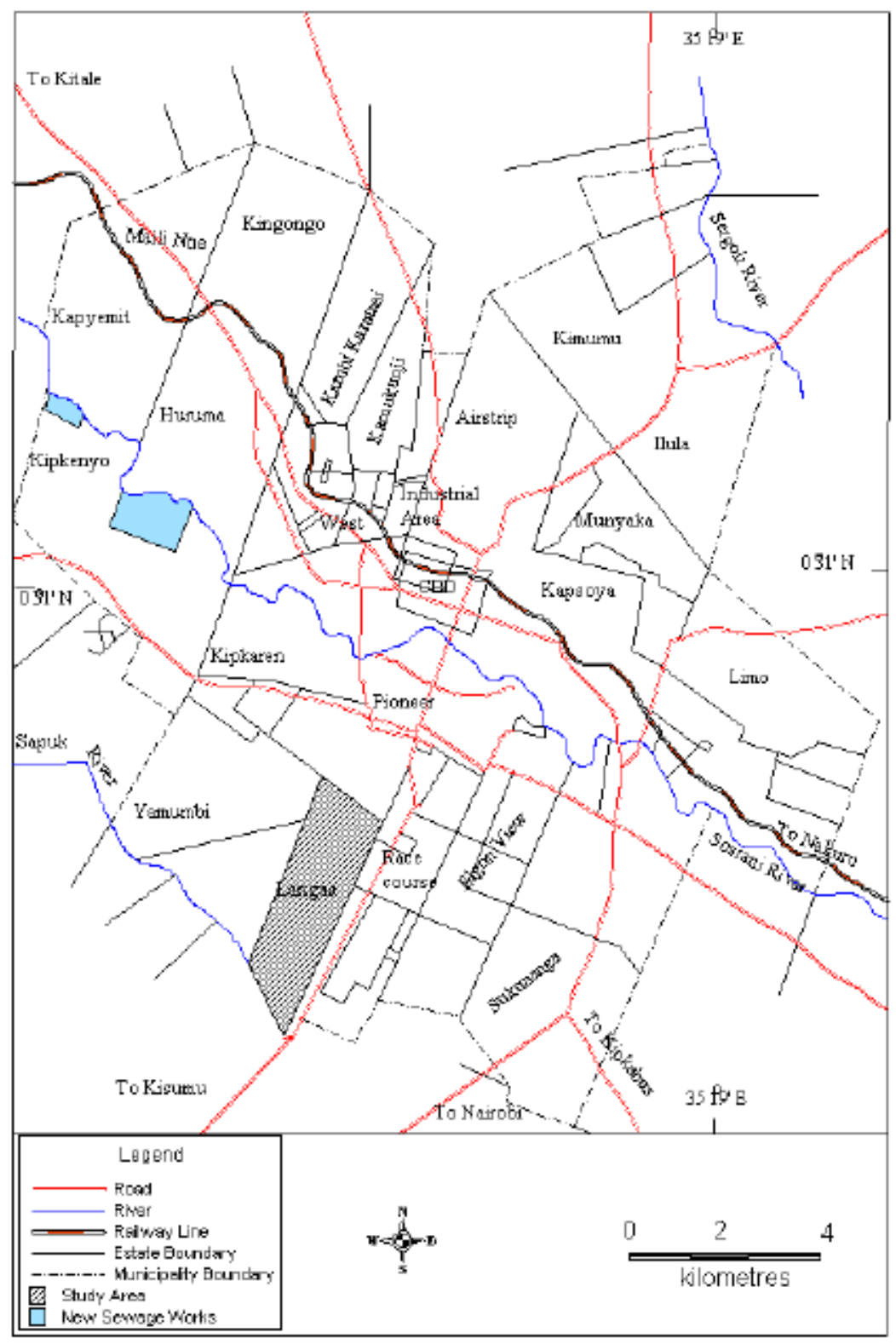

Figure 2: Estates within Eldoret Municipality Source: (Simiyu, 2012)

\section{Study design, Sampling and Data collection}

A survey design was adopted in this study. The household sample size was determined through estimate from the formulae proposed by Israel. (1992) which states that:

$$
\mathrm{n}=\frac{\mathrm{N}}{1+\mathrm{N}(\mathrm{e})^{2}}
$$

$\mathrm{N}=1051$ households, $\mathrm{e}=0.07(7 \%)$, therefore from the calculations a sample size (n) of 170 households was obtained. A systematic sampling technique was employed where every $5^{\text {th }}$ household was picked to be the part of the representative sample. The head of the household and in their absence the partner were issued with the questionnaire to fill and observation used to ascertain the data collected. The data was collected in December, 2014. The respondents were to note the order of frequency using Likert Scale of 4 whereby 
4 = More frequently (MF), 3 = frequently $(\mathrm{F}), 2=\operatorname{rarely}(\mathrm{R}), 1=\operatorname{Never}(\mathrm{N})\}$.

\section{Data Analysis}

The data were analyzed using descriptive statistics in form of mean, standard deviations and Chi-Square using SPSS 16.0 Version software whereas the analyzed data were presented in form of tables, graphs and percentages.

\section{Results}

\section{Demographics of respondents}

The result indicated that majority $(61.18 \%)$ of the respondents were women whereas men were $38.82 \%$. The study established that $14.12 \%$ of the respondents had attained lower primary education, $27.65 \%$ had upper primary education, $20.59 \%$ had attained secondary education, $34.12 \%$ had post secondary education and $3.53 \%$ of the respondents had no formal education.

\section{Current level of access to information about SWM}

The respondents were asked whether they were accessible to information about managing solid waste within Langas Estate in Eldoret Municipality. The result indicated majority $(53.53 \%)$ of the respondents were accessible to information about SWM whereas $46.47 \%$ were not (Table 1).

Table 1: Responses accessible to information related to SWM

\begin{tabular}{ccc}
\hline Accessible to information & Frequency & Percent \\
\hline Yes & 91 & 53.53 \\
No & 79 & 46.47 \\
Total & 170 & 100.0 \\
\hline
\end{tabular}

Table 2: Respondents ratings of their main sources of information about SWM

\begin{tabular}{llllll}
\hline Sources of information & MF & F & R & N & Total Score (Mean) \\
\hline Public meetings & 19 & 27 & 23 & 101 & $304(1.79)$ \\
Posters and print media & 26 & 48 & 27 & 69 & $371(2.18)$ \\
NEMA/EMC officers & 8 & 17 & 21 & 124 & $241(1.42)$ \\
Television and radio & 77 & 84 & 6 & 3 & $575(3.38)$ \\
Friends and neighbours & 68 & 95 & 19 & 0 & $595(3.50)$ \\
At school & 78 & 86 & 4 & 2 & $580(3.41)$ \\
\hline
\end{tabular}

*EMC stands for Eldoret Municipal Council

\section{Source of information about SWM}

The respondents were asked where they obtained information related to SWM within Langas Estate. To establish the most frequently and rare source of information, scoring was done where the mean above 3.0 was considered frequent whereas the mean below 3.0 was considered rare.

The most frequent sources of information based on the mean score for the respondents were from friends and neighbours (3.50), the school (3.41), and the television and radio (3.38), whereas the rare sources of information included posters and print media (2.18), public meetings (1.79) and the NEMA/EMC officers (1.42) as shown in Table 2.

Distance from main sources of information for $S W M$

The distance from the main sources of information about SWM influences the diffusion of information. The mean distance from the main source of information for the respondents was established to be $2.06 \pm 1.131 \mathrm{Km}$ away. There was need to establish if there is significant relationship between distance 
from source of information and access to information. This was tested by Chi-square analysis and the results were as represented in Table 3.

Table 3: A Cross tabulation between Distance from main source of information and access to information

\begin{tabular}{lllll}
\hline & & \multicolumn{2}{l}{ Access to information } & Total \\
\cline { 1 - 3 } Distance from main source & $<1 \mathrm{~km}$ & $45(26.47 \%)$ & $24(14.12 \%)$ & $69(40.59 \%)$ \\
& $1-2 \mathrm{~km}$ & $20(11.76 \%)$ & $27(15.88 \%)$ & $47(27.64 \%)$ \\
& $3-4 \mathrm{~km}$ & $23(13.53 \%)$ & $13(7.65 \%)$ & $36(21.18 \%)$ \\
& $5-6 \mathrm{~km}$ & $3(1.76 \%)$ & $7(4.12 \%)$ & $10(5.88 \%)$ \\
Total & $>6 \mathrm{~km}$ & $0(0.00 \%)$ & $8(4.71 \%)$ & $8(4.71 \%)$ \\
& & $91(53.52 \%)$ & $79(46.48 \%)$ & $170(100 \%)$ \\
\hline
\end{tabular}

$* \chi^{2}=31.857, \mathrm{df}=4, \mathrm{p}=0.000<0.05$

Majority of the respondents $(40.59 \%)$ were less than one kilometres away from the main source among them $26.47 \%$ were accessible to information whereas a few $(4.71 \%)$ of the respondents were more than six kilometres away from the main source of information among then none was accessible to information (Table 3). The Chi-square analysis indicates that there is a significant relationship $(p=0.000<0.05)$ between distance from the main source of information and access to information.

Main challenges of access to information about SWM in Eldoret Municipality

The barriers to access to information about SWM in Langas Estate were established because they determine the level of access to information. The respondents were asked to state the main and minor challenges they encountered while seeking information.

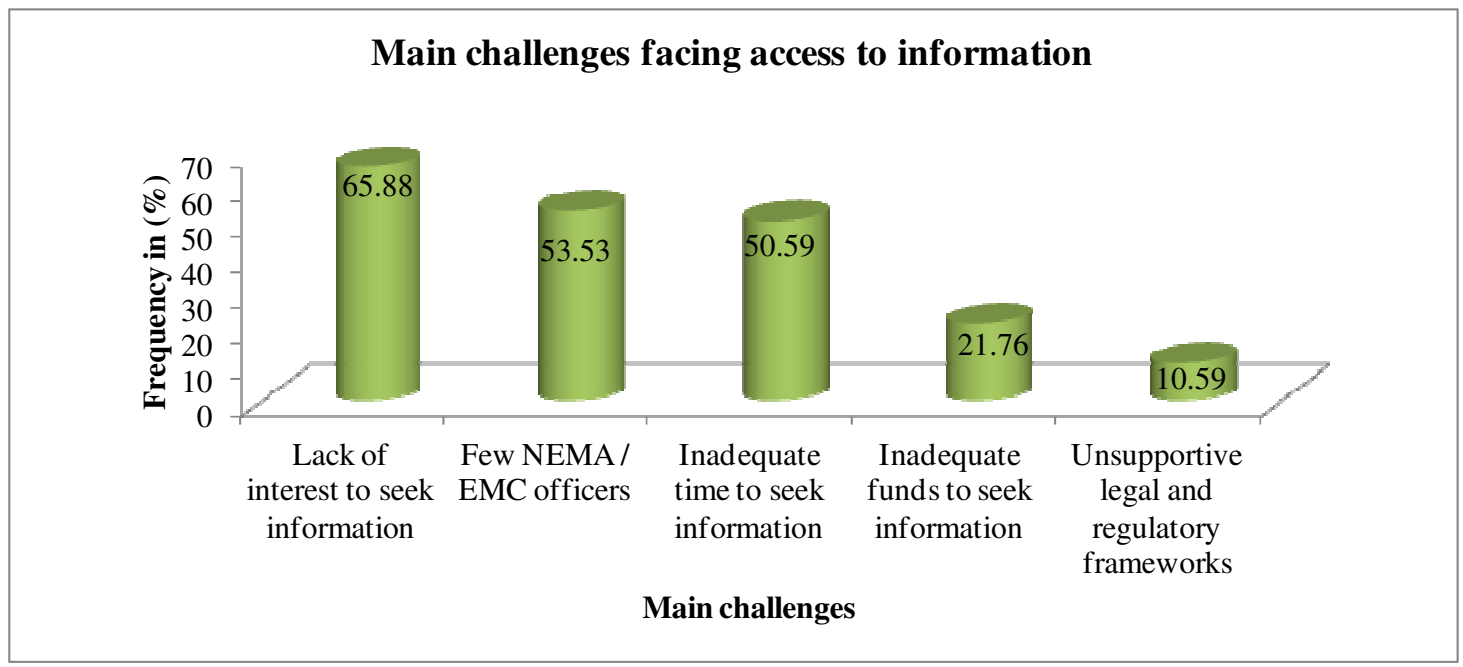

Figure 3: Main challenges of access to information about SWM

* Multiple responses

Majority of respondents $(65.88 \%)$ said that the main challenge was lack of interest to seek information by respondents,
$53.53 \%$ said few NEMA/EMC officers in Langas estate, $50.59 \%$ reported inadequate time, $21.76 \%$ noted inadequate funds to 
seek information whereas a few (10.59\%) reported unsupportive legal and regulatory frameworks (Figure 3).

Influence of access to information about $S W M$

The third objective of this paper was to assess the influence of access to information about SWM. The study established whether respondents were influenced by access to information about SWM. The respondents were asked: Do access to information influence you in SWM?

Table 4: Respondents influenced by access to information about SWM

\begin{tabular}{ccc}
\hline Influenced by access to information & Frequency & Percentage (\%) \\
\hline Yes & 98 & 57.65 \\
No & 72 & 42.35 \\
Total & 170 & $100 \%$ \\
\hline
\end{tabular}

Majority (57.65\%) said that they were influenced by access to information whereas $42.35 \%$ were not (Table 4). According to Mukui (2013) urban dwellers are accessible to information but they rarely put it in practice because of carelessness and the issue of socialization whereby women are believed to be the ones to keep the environment clean. It was important to assess whether there was significant relationship between access to information about solid waste and the influence of information. The Chi-Square analysis was used for analysis and the results are shown in Table 5.

Table 5: A Cross tabulation between access to information and influenced by information

\begin{tabular}{lllll}
\hline & & \multicolumn{2}{l}{ Influenced by information } & \\
\cline { 1 - 4 } Access to information & Yes & No & Total \\
& No & $47(27.65 \%)$ & $44(25.88 \%)$ & $91(53.53 \%)$ \\
Total & & $96(56.47 \%)$ & $74(43.53 \%)$ & $170(100 \%)$ \\
\hline
\end{tabular}

$* \chi^{2}=1.852, \mathrm{df}=1, \mathrm{p}=0.173>0.05$

The result indicated that majority of the respondents $(53.53 \%)$ were accessible to information among them $27.65 \%$ were influenced by the information they got whereas $25.88 \%$ were not influenced by the information they were accessible to (Table 5). The analysis by Chi-square $\left(x^{2}=\right.$ 1.852 , df $=1, \mathrm{p}=0.173$ ) indicated that there is no significant relationship between access to information and its influence on solid waste management.

\section{How access to information influences SWM}

It was essential to establish how the respondents are influenced by access to information. This was achieved by asking the respondents to state their level of agreement based on Likert scale of $5\{5=$ Strongly Agree (SA), $4=$ Agree (A), $3=$ Neutral (N), 2 = Disagree (D) and $1=$ Strongly Disagree (SD) $\}$ to the 5 items. 
The items were scored such that the most favourable response was mean above 4 whereas the least favourable response was mean below 3. The responses were as shown in Table 6.

Table 6: Respondents ratings of how they are influenced by access to information about SWM

\begin{tabular}{lllllll}
\hline Influence of access to information & SA & A & N & D & SD & Total \\
\hline Increases use of dust bins and landfills & 82 & 47 & 21 & 14 & 6 & $695(4.09)$ \\
Promotes reuse and recycling of waste & 69 & 43 & 37 & 18 & 3 & $667(3.92)$ \\
Willingness to pay for waste disposal & 38 & 47 & 54 & 29 & 2 & $600(3.53)$ \\
Enhances good rapport among stakeholders & 33 & 46 & 79 & 9 & 3 & $597(3.51)$ \\
Separation of solid wastes before disposing & 69 & 64 & 23 & 13 & 1 & $697(4.10)$ \\
\hline
\end{tabular}

* Multiple responses

The respondents revealed that access to information about solid waste mainly promoted separation of solid wastes before disposing (4.10), increased use of dust bins and landfills (4.09), then promoted reuse and recycling of solid waste (3.92), then increased willingness to pay for waste disposal (3.53), and the least influenced was that it enhanced good rapport among stakeholders concerned with SWM (3.51)

Respondents' suggested ways in which access to information about SWM

The respondents were asked to state ways in which access to information could be enhanced within Langas Estate. The responses were analyzed and presented in the Figure 4.

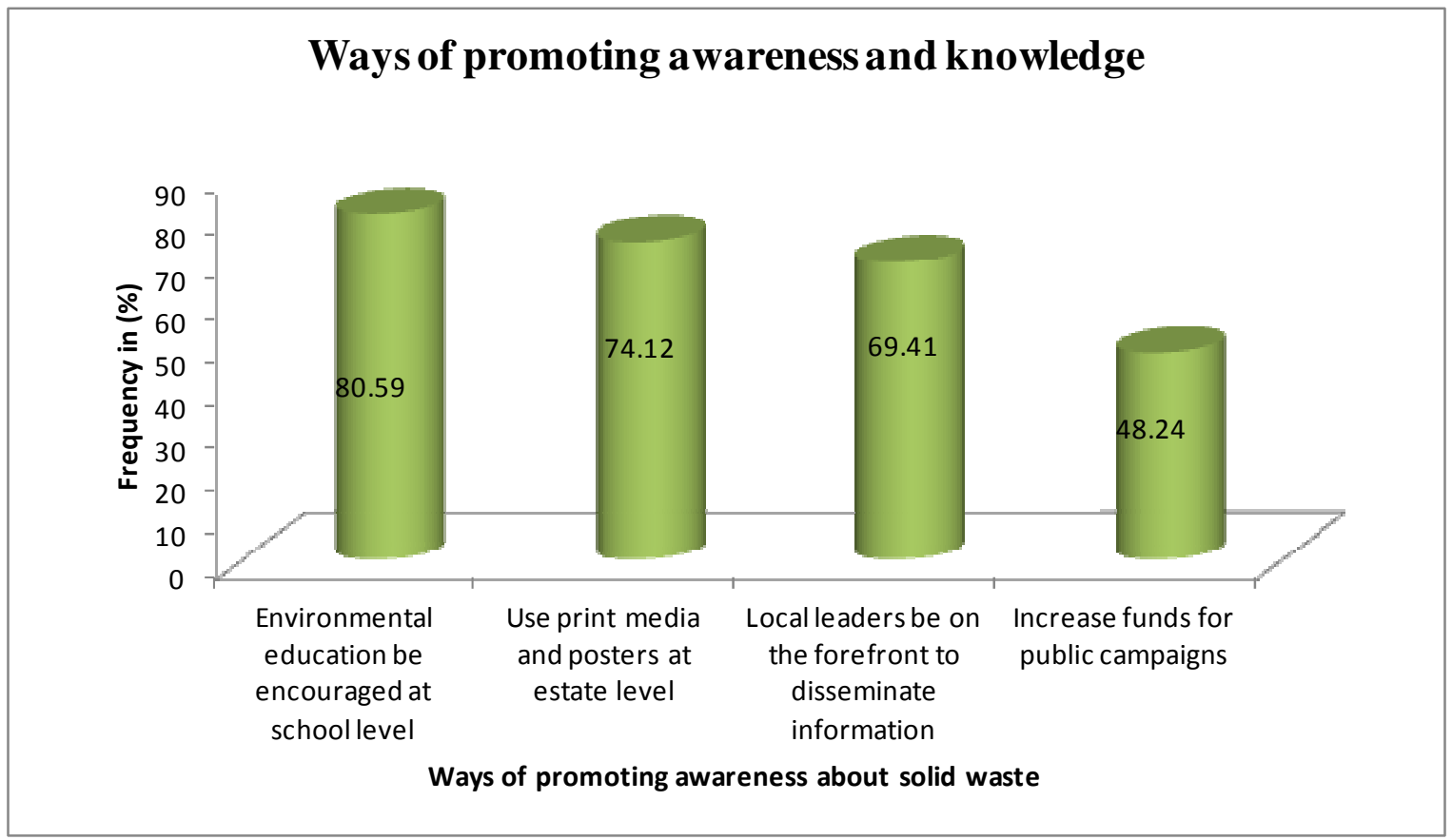

Figure 4: A bar graph representing ways of promoting access to information

Majority of the respondents $(80.59 \%)$ said through environmental education at school level, $74.12 \%$ reported increase the use of print media and posters at estate level, $69.41 \%$ noted local leaders to be at the forefront to disseminate information, and others (48.24\%) said increase of funds for public campaigns (Figure 4). 


\section{Discussion}

\section{Demographics}

Abul (2010) while studying environmental and health impacts of solid waste in Manzini (Swaziland) found out that $62.8 \%$ were women whereas $37.2 \%$ were men. Majority of the respondents were women because they were more likely to be found at home compared to their husbands and they are concerned with solid waste disposal at household level (Minn et al, 2010; Mukui, 2013).This implies that strategies meant to enhance sustainable solid waste management should be directed towards encouraging both men and women towards proper solid waste management. Mukui (2013) established that only $1 \%$ of respondents were illiterate in his studies carried out in Nyeri Town (Kenya) which agrees with the current study. Since most respondents had attained high level of education they were expected to have ability to understand the information that is provided to them through public awareness programs.

\section{Access to and sources of information}

Access to information is critical in understanding the mechanisms of proper SWM and change of negative attitudes towards participating in SWM. In Langas Estate, most of the respondents were accessible to information through friends, neighbours, school, television and radio, posters and print media, public meetings and the NEMA/EMC officers (Okalebo et al., 2014; Sarker et al., 2012). The respondents were taught environmental education while they were still in school in subjects like English, Geography, Science and social studies (Mbalisi and Offor, 2012). The mass media both visual and audio played a major role in providing information to households (Sarker, et al 2012). Most of the urban dwellers rarely attend public meetings such as public rallies, workshops and seminars organized by City authorities, community based organizations, and Non-Governmental Organizations (Mbalisi and Offor, 2012; Sarker et al, 2012).

\section{Distance and Access to information}

The distance from the source of information plays a critical role in access to information. Therefore an increase in distance reduced the access to information because of the need for finances to travel and time (Chepkole, 2014).

\section{Challenges affecting access to information}

Lack of interest to seek information was attributed to negative attitude towards participation in urban SWM and the belief that it is the sole role of Municipal council workers paid to do the job and women (Minn et al, 2010; Mukui, 2013). Due to economic down turn most of the urban dwellers such as women living in informal settlements are busy participating in economic activities thus ignoring social as well as environmental issues in their neighbourhood (Mukui, 2013).

\section{Influence of access to information on resident's attitudes}

Okalebo et al (2014), argues that waste reduction from the source is still low but this can be enhanced through awareness and access to information. According to Minn et al. (2010), urban dwellers tend to assume that waste collection is the duty of municipal authorities, although these dwellers are the main producers of household wastes. Education can bring a change in behaviour of stakeholders and awareness influences negative perceptions of the people towards urban solid waste management (Mbalisi and Offor, 2012; Oyoo et al., 2011).

\section{Ways of promoting access to information}

The respondents noted that it was necessary to increase the use of print media and posters at estate level which should be placed on watering points or business premises as well on billboards. In 
addition, the local leaders such as village elders, chiefs, ward administrators, county representatives and women leaders should to be at the forefront to disseminate information. Lastly the respondents reported that there was a great need increase funds for public campaigns and training of Municipal officers to cover the whole Municipality.

\section{Conclusion}

It has been established that most of the residents are accessible to information concerning solid waste through schools, neighbours, friends, mass media and Municipal officers. However, this access to information is limited by lack of interest, inadequate funds, insufficient time to seek information and few public health officers. Generally, those that were accessible to information were able to separate waste, reuse, recycle, recover energy, composting and willing to pay for disposal whereas others were not practicing what they know due to career related issues or they had employed house helps. Thus, access to information has an influence on proper SWM in Eldoret Municipality and it has to be promoted through school, media, NEMA/EMC officers, friends and neighbours.

\section{Recommendations}

Proper disposal of solid waste is a challenge in most urban areas of developing countries including Kenya. Therefore in an effort to reduce indiscriminate disposal of solid waste on the vacant plots the following should be done:

EMC should educate urban residents through road shows, distribution of leaflets and pamphlets, radio and television to encourage residents to separate their waste at source, dispose waste in the dust bins, recycle and reuse the waste. The schools and other public institutions like hospitals, religious, local administration among others should encourage the youth, women and the elderly on adopting proper SWM. There is a need to have an environmental awareness week within the estates to ensure both formal and self employed individuals are educated on importance of proper management of waste twice per year. The respondents reported that women leaders should encourage women who lack confidence to participate in public meetings, workshops and seminars so that they are educated on various ways of managing solid waste. It was revealed that more personnel should be trained on solid waste reduction, recycling, reuse, composting and energy recovery so that they train the residents that are inaccessible to information due to location factors.

\section{Acknowledgements}

We would like to thank the 170 respondents of Langas Estate in Eldoret Municipality that were more than willing to disclose more information in relation to access to information SWM. Our appreciation goes to the Village Elder of Langas Estate in Eldoret Municipality that was instrumental in helping us to familiarize with the estate and the respondents.

\section{References}

Abul, S. (2010). Environmental and Health Impact of Solid Waste Disposal at Mangwaneni Dumpsite in Manzini: Swaziland. Journal of Sustainable Development in Africa, 12(7): 64-78. ISSN: 1520-5509.

Chepkole, W.K. (2014). Determinants of Household Solid Waste Management in Kenya: A Case of Eldoret Municipality. Master's Research Project, University of Nairobi, Kenya. 
Israel, G. D. (1992). Sampling the Evidence of Extension Program Impact, Program

Kapepula, K., Colson, G., Sabri, K., and Thonart, P (2007). A Multiple Criteria Analysis for household solid waste management in Urban Community of Dakar, Senegal. Waste Management, 27: 1690-1705.

Mangizvo, R.V. (2007). Challenges of Solid Waste Management in the Central Business District of the City of Gweru in Zimbabwe. Journal of Sustainable Development in Africa 9(3): 134-145. ISSN: 1520-5509.

Mbalisi, O. F., and Offor, B.O. (2012). Imperatives of Environmental Education and Awareness creation to Solid Waste Management in Nigeria. Academic Research International, 3(2). ISSN: 2223-9944.

Minn, Z., Srisontisuk, S., and Laohasiriwong, W (2010). Promoting people's participating in Solid Waste Management in Myanmar. Research Journal of Environmental Sciences, 4: 209-222.

Doi: 10.3923/rjes.2010.209.222.

Mukui, S.J. (2013). Factors influencing Household Solid Waste Management in Urban Nyeri Municipality,

Kenya. Ethiopian Journal of Environmental Studies and Management, 6(3): 280-285. http://dx.doi.org/10.4314/ejesm.v6i3. 8

Musyoka, R. (2004). Informal land delivery processes in Eldoret, Kenya: Summary of findings and policy implications. Policy Brief 3, University of Birmingham: International Development Department of School of Public Policy.

National Environmental Management Authority (2014). The National Solid
Waste Management Strategy. Kenya: National Environmental Management Authority, Government Printer.

Ogwueleka, T. C. (2009). Municipal Solid Waste Characteristics and Management in Nigeria. Iran Journal Environmental Health Sciences and Engineering, 6(3): 173-180.

Okalebo, S.E., Opata, G.P., and Mwasi, B. N. (2014). An Analysis of the Household Solid Waste Generation Patterns and Prevailing Management Practices in Eldoret town, Kenya. International Journal of Agricultural Policy and Research, 2(2): 76-89. ISSN: 2350-1561

Opata, G., Mulongo, L., Omuterema, S., and Ng'etich, J.K. (2013). Urbanization and Urban Environmental Development Control Policies and Practices in Kenya. Research Journal in Organizational Psychology \& Educational Studies 2(3): 132-138. ISSN: 2276-8475.

Oyoo, R., Leemans, R., and Mol, A.P.J. (2011). Future Projections of Urban waste flows and their impacts in African Metropolises Cities. International Journal of Environmental Research, 5(3): 705724. ISSN: 1735-6865.

Sarker, B.C., Sarker, S.K., Islam, M.S., and Sharman, S. (2012). Public awareness about Disposal of solid waste and its impact: A study in Tangail Pourashava, Tangail, Bangladesh. Journal of Environmental Science \& Natural Resources, 5(2): 239-244.

Simiyu, R, (2012). "I don't tell my husband about vegetable sales": Gender aspects of urban agriculture in Eldoret, Kenya. Doctoral Thesis, Leiden University, The Netherlands. 